\title{
Update of annual calving front lines for 47 marine terminating outlet glaciers in Greenland (1999-2018)
}

\author{
Jonas K. Andersen", Robert S. Fausto*1, Karina Hansen", Jason E. Box ${ }^{1}$ and the PROMICE project team ${ }^{* *}$ \\ ${ }^{* *}$ Signe B. Andersen', Andreas P. Ahlstrøm¹, Dirk van As', Michele Citterio1, William Colgan', Nanna B. Karlsson', \\ Kristian K. Kjeldsen', Niels J. Korsgaard', Signe H. Larsen', Kenneth D. Mankoff', Allan $\varnothing$. Pedersen', \\ Christopher L. Shields ${ }^{1}$, Anne Solgaard ${ }^{1}$ and Baptiste Vandecrux ${ }^{1}$
}

\author{
RESEARCH ARTICLE | OPEN ACCESS \\ GEUS Bulletin Vol 43 | e2019430202 | Published online: 26 June 2019 \\ https://doi.org/10.34194/GEUSB-201943-02-02
}

The Greenland ice sheet has been losing mass in response to increased surface melting (Khan et al. 2015; van den Broeke et al. 2017) as well as discharge of ice from marine terminating outlet glaciers (van den Broeke et al. 2009; Box et al. 2018). Marine terminating outlet glaciers flow to the ocean where they lose mass by e.g. iceberg calving. Currently, the mass loss from the Greenland ice sheet is the largest Arctic contributor to global sea-level rise (van den Broeke et al. 2009, 2017; Box et al. 2018). Therefore, monitoring changes in the Greenland ice sheet is essential to provide policy makers with reliable data.

There is a consensus that most marine terminating outlet glaciers have retreated in recent decades, and that the increased calving rates are a response to recent atmospheric and oceanic warming (e.g. Box et al.2018; Moon et al. 2018). The rate of dynamic mass loss is determined by changes of the glacier calving front (i.e. its terminus) position, ice thickness and changes in ice flow. Ocean temperature and fjord circulation also influence the calving front stability by melting the glacier below the water line, thinning the ice that is in contact with water (Moon et al. 2014). Change in calving front position is therefore an important indicator for monitoring the dynamic behaviour of the upstream area of the ice sheet, which is further modulated by local topographic features and buttressing effects (Rignot \& Kanagaratnam 2006; Nick et al. 2009).

The Programme for Monitoring of the Greenland Ice Sheet (PROMICE) is dedicated to monitoring changes in the mass budget of the Greenland ice sheet, including monitoring of the calving front lines of marine terminating outlet glaciers. Here, we present an updated collection of annual measurements of end-of-melt-season calving front lines for 47 marine terminating outlet glaciers in Greenland between 1999 and 2018. We also present an example application of

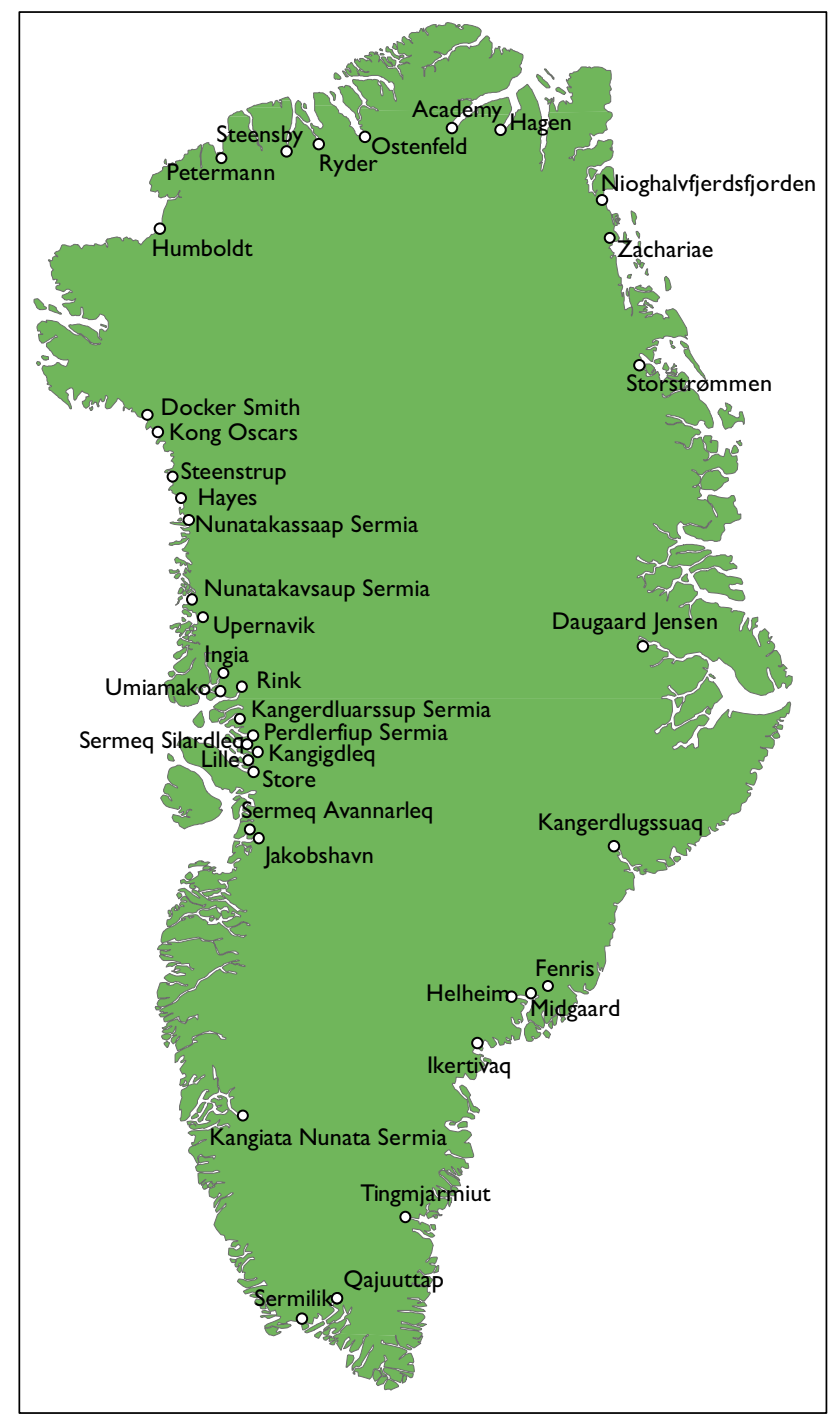

Fig. 1. Location of each of the surveyed outlet glaciers (Table 2). 
Table 1:

Overview of images used in the mapping of calving front lines

\begin{tabular}{lcccc}
\hline Satellite & Sensor & Band & Resolution & $\begin{array}{c}\text { Image } \\
\text { coverage (\%) }\end{array}$ \\
Landsat 5 & TM & 3 & $30 \mathrm{~m}$ & 0.8 \\
Landsat 7 & ETM+ & 8 & $15 \mathrm{~m}$ & 62.1 \\
Landsat 7 & ETM+ & $3-5$ & $30 \mathrm{~m}$ & 4.9 \\
Landsat 8 & OLI & 8 & $15 \mathrm{~m}$ & 0.4 \\
Landsat 8 & OLI & $4-6$ & $30 \mathrm{~m}$ & 22.0 \\
Terra & ASTER & $1-3$ & $15 \mathrm{~m}$ & 4.5 \\
Sentinel-2 & MSI & 8 & $10 \mathrm{~m}$ & 5.3 \\
\hline
\end{tabular}

Image coverage indicates the number of images used from each sensor as a percentage of the total number of images used. Auxiliary images used in cases of distortion due to clouds or missing data bands in Landsat 7 images are not counted. Landsat images can be obtained from the USGS (https:// earthexplorer.usgs.gov/). Sentinel-2 data can be obtained from the Copernicus Open Access Hub (https://scihub.copernicus.eu/).

the data set, in which we estimate area changes for this group of glaciers since 1999. The Greenland calving front lines were measured from optical satellite imagery obtained from Landsat, Aster, and Sentinel-2 (Table 1). The PROMICE calving front product is freely available for download as ESRI shapefiles (https://doi.10.22008/promice/data/calving_front_lines).

\section{Methodology}

Calving front lines were digitised through manual delineation in optical satellite images at the end of melt season every year from 1999 to 2018. The end of melt season was determined for each glacier by comparing a series of images from July-November (dependent on latitude) and selecting the one in which the glacier is at its minimum position. Prior to 2018 , calving front lines were digitised primarily using Landsat-7 and Landsat- 8 images. In 2018, front lines were digitised solely using Sentinel-2 imagery. We used mainly the panchromatic band to identify front line positions in Landsat-7 images, a combination of three visible/NIR bands in Landsat- 8 images and the NIR band in Sentinel-2 images (Table 1). The resulting product is a collection of shapefiles, containing a polyline for each glacier for each year in the measurement period (1999-2018). The product comprises 47 of the largest Greenland marine terminating outlet glaciers in the standard WGS-84 (EPSG:4326) projection (see the glacier location map; Fig. 1 and Table 2). While the total number of glaciers is arbitrary, the ensemble of glaciers was selected to include the largest marine terminating outlet glaciers (measured in width) and to comprise glaciers from all along the Greenland coast.
Table 2:

Overview of net area change, average annual area change, and width for the 47 tidewater glaciers monitored between 1999-2018.

\begin{tabular}{|c|c|c|c|c|c|}
\hline Glacier name & $\begin{array}{l}\text { Lat. } \\
\left({ }^{\circ} \mathrm{N}\right)\end{array}$ & $\begin{array}{l}\text { Long. } \\
\left({ }^{\circ} \mathrm{E}\right)\end{array}$ & $\begin{array}{l}\text { Width } \\
(\mathrm{km})\end{array}$ & $\begin{array}{c}\text { Net area } \\
\text { change } \\
\left(\mathrm{km}^{2}\right)\end{array}$ & $\begin{array}{c}\text { Average area } \\
\text { change } \\
\left(\mathrm{km}^{2} \mathrm{a}^{-1}\right)\end{array}$ \\
\hline Zachariae & 78.90 & -20.14 & 24.6 & -409.6 & -21.6 \\
\hline Petermann & 80.10 & -61.17 & 17.4 & -289.5 & -15.2 \\
\hline Humboldt & 79.50 & -64.61 & 89.0 & -259.4 & -13.7 \\
\hline Hagen & 81.53 & -28.50 & 9.1 & -172.8 & -9.1 \\
\hline Jakobshavn & 69.18 & -49.73 & 11.4 & -137.0 & -7.2 \\
\hline \multicolumn{6}{|l|}{ Nunatakassaap } \\
\hline Sermia & 74.62 & -56.34 & 5.4 & -70.5 & -3.7 \\
\hline Steensby & 81.20 & -53.90 & 4.5 & -69.5 & -3.7 \\
\hline Ostenfeld & 81.60 & -45.20 & 7.0 & -65.0 & -3.4 \\
\hline 79 Fjorden & 79.60 & -20.17 & 42.2 & -51.7 & -2.7 \\
\hline Steenstrup & 75.28 & -57.89 & 16.2 & -50.8 & -2.7 \\
\hline Kangerdlugssuaq & 68.61 & -32.93 & 6.0 & -45.9 & -2.4 \\
\hline Midgaard & 66.45 & -36.73 & 3.8 & -40.9 & -2.2 \\
\hline Upernavik A & 73.00 & -54.47 & 7.3 & -40.4 & -2.1 \\
\hline Helheim & 66.36 & -38.12 & 5.8 & -34.6 & -1.8 \\
\hline Inngia & 72.03 & -52.61 & 4.0 & -31.7 & -1.7 \\
\hline Kong Oscars & 75.98 & -59.79 & 4.2 & -21.5 & -1.1 \\
\hline Sermeq Silardleq & 70.80 & -50.80 & 3.3 & -19.7 & -1.0 \\
\hline Academy & 81.50 & -32.65 & 8.8 & -14.2 & -0.7 \\
\hline Umiamako & 71.72 & -52.44 & 2.9 & -13.3 & -0.7 \\
\hline Ikertivaq A & 65.67 & -39.60 & 3.2 & -13.1 & -0.7 \\
\hline Docker-Smith & 76.24 & -61.00 & 5.1 & -13.1 & -0.7 \\
\hline Upernavik B & 72.94 & -54.38 & 3.8 & -12.4 & -0.7 \\
\hline Tingmjarmiut & 62.76 & -43.18 & 2.5 & -11.3 & -0.6 \\
\hline Ikertivaq D & 65.49 & -40.06 & 7.9 & -10.6 & -0.6 \\
\hline Daugaard-Jensen & 71.92 & -28.57 & 5.3 & -10.1 & -0.5 \\
\hline Sermeq Avannarleq & 69.36 & -50.31 & 4.4 & -9.5 & -0.5 \\
\hline \multicolumn{5}{|l|}{ Perdlerfiup } & -0.5 \\
\hline Sermia & 70.99 & -50.92 & 2.7 & -9.0 & -0.5 \\
\hline Ikertivaq C & 65.58 & -39.96 & 5.3 & -7.3 & -0.4 \\
\hline Fenris & 66.36 & -37.54 & 2.8 & -7.1 & -0.4 \\
\hline Sermilik & 61.00 & -45.95 & 1.5 & -6.3 & -0.3 \\
\hline \multicolumn{6}{|l|}{ Kangia Nunata } \\
\hline Sermia & 63.33 & -49.62 & 7.8 & -6.2 & -0.3 \\
\hline \multicolumn{5}{|l|}{ Kangerdluarssup } & -0.2 \\
\hline Sermia & 71.25 & -51.47 & 3.2 & -3.4 & -0.2 \\
\hline Upernavik D & 72.79 & -54.22 & 2.3 & -3.4 & -0.2 \\
\hline Upernavik E & 73.00 & -54.65 & 2.0 & -3.4 & -0.2 \\
\hline Lille & 70.43 & -50.51 & 2.1 & -2.8 & -0.1 \\
\hline Upernavik C & 72.85 & -54.33 & 6.3 & -2.7 & -0.1 \\
\hline Ryder & 81.30 & -49.90 & 8.0 & -2.3 & -0.1 \\
\hline Rink & 71.75 & -51.64 & 5.1 & 2.0 & 0.1 \\
\hline Upernavik F & 73.03 & -54.84 & 1.8 & -1.9 & -0.1 \\
\hline Kangigdleq & 70.72 & -50.64 & 2.9 & -0.8 & 0.0 \\
\hline Qajuuttap & 61.32 & -45.78 & 3.2 & 0.7 & 0.0 \\
\hline \multicolumn{6}{|l|}{ Nunatakavsaup } \\
\hline Sermia & 73.22 & -55.14 & 3.6 & 0.5 & 0.0 \\
\hline \multicolumn{6}{|l|}{ Kangerdlugssup } \\
\hline Sermerssua & 71.46 & -51.36 & 4.9 & -0.1 & 0.0 \\
\hline Store & 70.40 & -50.55 & 5.2 & -0.1 & 0.0 \\
\hline
\end{tabular}

The table is sorted by magnitude net area change. 
Fig. 2: Example image from Hayes glacier showing how area change is estimated from two consecutive calving front lines. The green line indicates the reference line. The calving front lines in 2012 and 2013 are depicted by blue and red lines, respectively. The glacier area change is computed as the area difference between the 2012 and 2013 polygons. The satellite image is an EU Copernicus Sentinel-2A image from 14 August 2018.

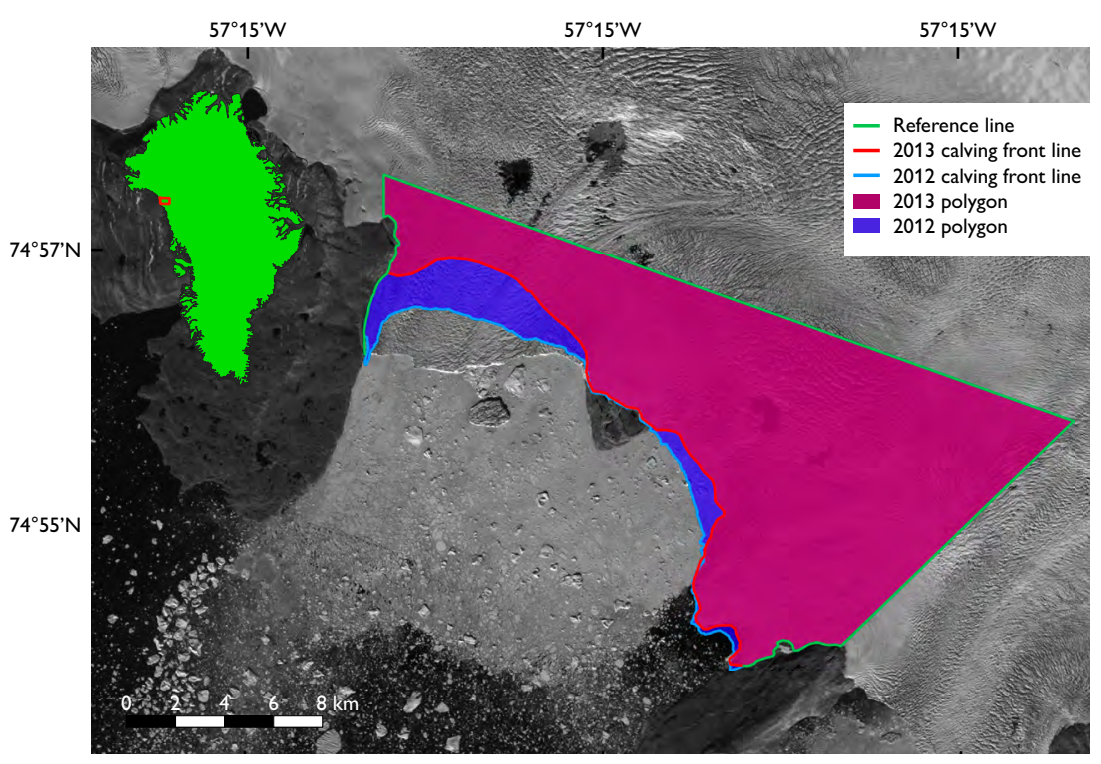

\section{Area change estimates since 1999}

Visualising annual calving front lines is a useful tool for identifying glacier retreat, advance or stable calving front lines (as shown in Fig. 2). Comparing sequential annual lines enables annual area change assessment for individual glaciers and for the whole ensemble, by selecting a constant reference line upstream of the glacier. The reference line is somewhat arbitrary, but when combined with each calving front line, we can generate a series of annual polygons. Annual area changes are then estimated as the area difference between consecutive polygons. For a thorough presentation of the methodology, see Jensen et al. (2016). Measuring the polygon area change is arguably a more robust method than measuring a one-dimensional change in glacier length, since it accounts for non-uniform changes to the shape of the calving front. Figure 2 shows an example, where the 2012 and 2013 calving front lines of Hayes glacier have each been combined with the same reference line, generating two polygons. The 2012-2013 area change is then computed as the 2013 polygon area minus the 2012 polygon area.

\section{Sources of uncertainty}

The two main sources of uncertainty in the PROMICE calving line product are the manual delineation of front lines and the timing of front-line mapping. In principle, a front line can be delineated from a given satellite image with the precision of a single image pixel. However, in practice such precise digitisation is not feasible as the exact position of the calving front line is often obstructed by shadows or thin clouds. Consequently, an uncertainty of about two image pixels is inherent in the manual digitisation process. On the ground, one pixel represents either $10 \mathrm{~m}$ or $15-30 \mathrm{~m}$ for the utilised Sentinel-2 and Landsat bands, respectively. For example, the error associated with the Petermann glacier area change is estimated to be around $1 \mathrm{~km}^{2}$ in a $15 \mathrm{~m}$ resolution image, or $0.7 \mathrm{~km}^{2}$ using a $10 \mathrm{~m}$ resolution image. This rough estimate is computed as four times the image pixel size multiplied by the glacier width (which is about $17.4 \mathrm{~km}$, cf. Table 2), representing an uncertainty of \pm 2 image pixels for each point in the front-line delineation process.

The end of the melt season for a given glacier is defined as the time at which the glacier is at its minimum position, i.e. when it has retreated the farthest. However, satellite coverage is limited, and a subset of images are unusable due to the presence of clouds, potentially causing the timing of the end of the melt season to be over- or under-estimated. Such a mistiming introduces uncertainty when computing annual area change, as area measurements are compared at different points in the season. The final uncertainty depends strongly on how many images are available, and whether the image is obstructed by clouds. Jensen et al. (2016) estimated the error due to mistiming to be within $1 \mathrm{~km}^{2}$ and highlighted image availability as the dominant source of error. The problem is somewhat alleviated by the availability of data from Sentinel-2, which provides images more frequently due to its short repeat pass time of five days.

Another source of error arises from an instrument failure on Landsat 7's Enhanced Thematic Mapper Plus (ETM+) sensor, resulting in bands of missing data across all Landsat 7 images from 2003 onwards. In images where one of these bands aligned with the calving front line in parallel, obstructing a major part of the front line, other images from within a few weeks were used to approximate the front-line 


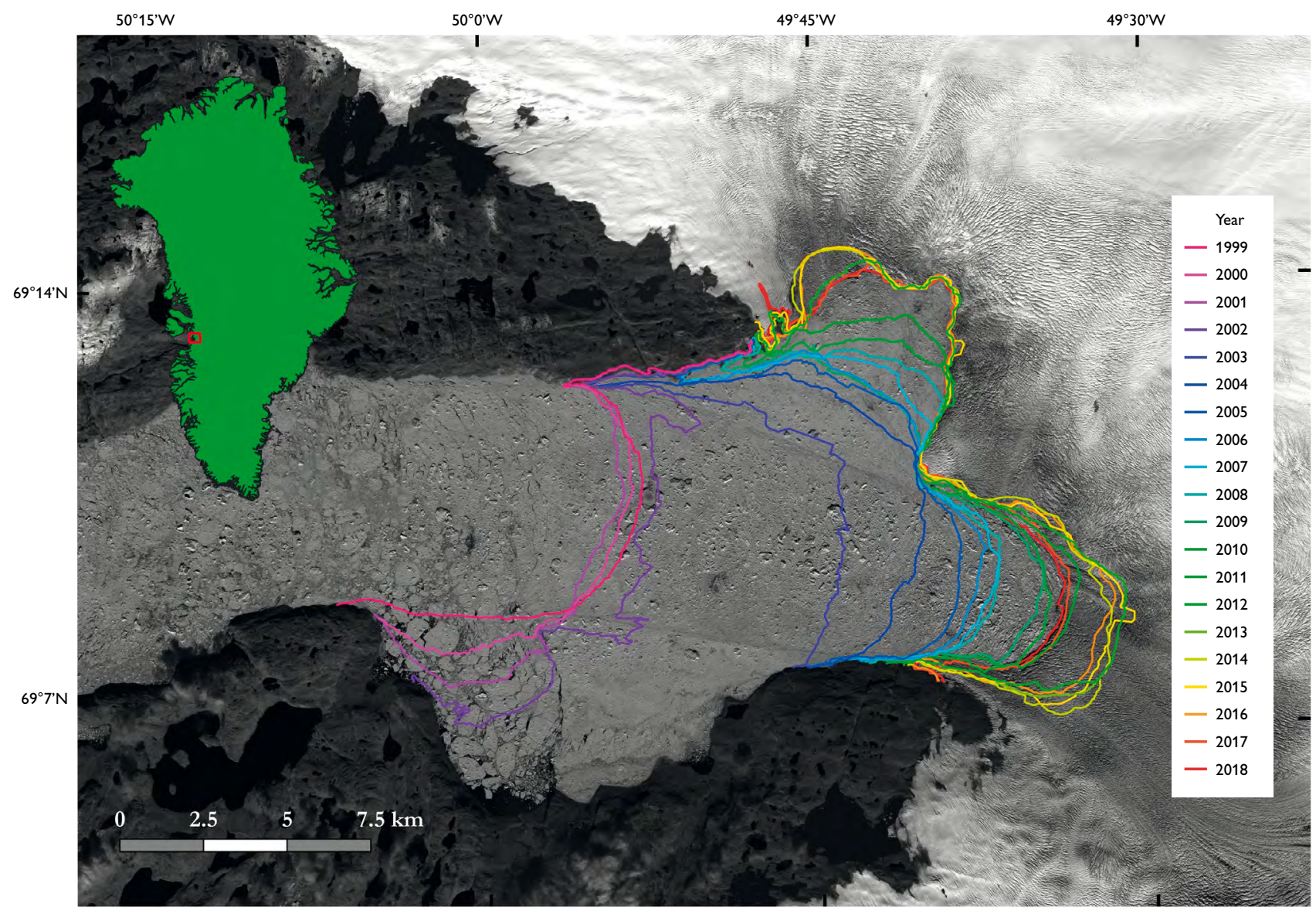

Fig. 3: Evolution of the calving front position of Jakobshavns Isbræ from manually delineated end-of-melt-season calving front lines spanning 1999 to 2018. The background image is from the EU Copernicus Sentinel-2B satellite from 4 September 2018. It is the same image that was used to delineate the 2018 front line.

position. If a band of missing data crossed the calving front line in a roughly perpendicular way, only obstructing a short stretch of the calving front line, the front line was simply digitised in a straight line across the missing data band. Again, this problem is alleviated by the use of Sentinel-2 or Landsat 8 data.

\section{Results and discussion}

As an example of the database, we present the calving front changes of Greenland's fastest flowing glacier, Jakobshavn Isbræ (Sermeq Kujalleq; Fig. 3). In 2017 the calving front advanced after more than $10 \mathrm{~km}$ of retreat between 1999 and 2016. The 2017 advance and stability into 2018 occurred in the faster flowing southern branch of the glacier.

A time series of the cumulative net area change for the period 1999-2018, estimated from the calving front line product of 47 glaciers, shows a net area loss of about $2100 \mathrm{~km}^{2}$ (Fig. 4). This equates to an average annual area loss of c. 110 $\mathrm{km}^{2}$ for these 47 glaciers since 1999 , which corresponds to an area roughly the size of Paris. The rate of area change varies substantially through time. The period 2007-2012 underwent a rapid loss of glacier area, compared to 2013-2018, in which glacier area was relatively stable, associated with a small area change. The year 2017-2018 stands out as the only period with net area gain $\left(+4.1 \mathrm{~km}^{2}\right)$. Table 2 provides the net area change as well as the average annual area change for each of the 47 surveyed glaciers. Nearly all of the investigated marine terminating outlet glaciers show a negative net area change since 1999 , indicating a retreat. Only three glaciers (Rink, Nunatakavsaup Sermia and Qajuuttap) show a positive net area change. There is substantial variation between the glaciers in the ensemble, but a few of the large glaciers, such as Humboldt, Petermann, Zachariae, and Jakobshavn, are responsible for a considerable amount of the total ensemble net area change observed in Fig. 4. Other glaciers such as Store and Nunatakavsaup Sermia show a net area change very close to zero. The area change of two glaciers is not directly comparable; a wider glacier will tend to show larger area changes than a narrower one. Alternatively, to compare 


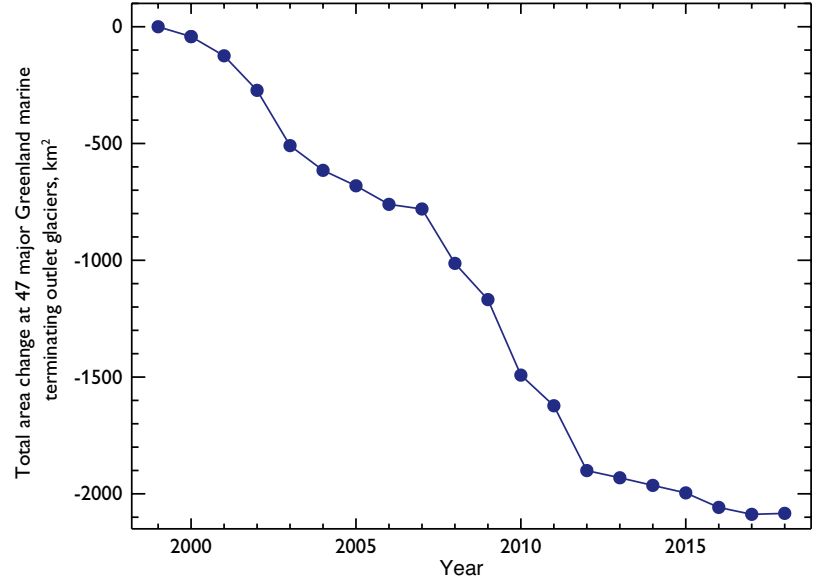

Fig. 4: Cumulative net area change for 47 Greenland marine terminating outlet glaciers during the period 1999-2018. Area changes were generated from the PROMICE calving front line product (https://doi.10.22008/ promice/data/calving_front_lines).

the area change of two glaciers, one could compute an estimate of the one-dimensional movement of each glacier as the obtained area change normalised (i.e. divided) by the glacier width.

We anticipate the updated PROMICE front line data set to be a useful addition to statistical investigations of glacier behaviour in Greenland. Questions remain as to the sensitivity of glacier area change to various climate parameters such as atmospheric forcing, sea-surface temperature, sea-ice concentration and the North Atlantic Oscillation (NAO). Jensen et al. (2016) found significant correlations between glacier area change and climate parameters for the period 1999-2013, dependent on geographical region. The reduction in ice-area loss in Jakobshavn Isbræ in 2017-2018 (Fig. 3) coincides with anomalously low melt-season temperatures, but Kazendar et al. (2019) pointed to colder ocean waters as the primary cause. Bevis et al. (2019) supported the notion of inter-annual variations in surface melting, driven by the $\mathrm{NAO}$, as an indicator of variability in Greenland mass loss. A physical mechanism linking summer air temperature and the front area of marine terminating outlet glaciers is the so-called hydrofracture, in which increased air temperature increases the supply of meltwater. More meltwater increases the availability and weight of water filling surface depressions. Water being denser than ice, adds an additional stress that can disaggregate the ice, especially along fractures (e.g. Weertman 1973; van der Veen 1998). With the PROMICE calving front line product, the time series of calving front line measurements is extended and five more glaciers are added to the ensemble, which serves to improve the accuracy of such statistical investigations performed by Jensen et al. (2016).
The calving front line product can also be used to compute ice velocity along a glacier flow line. Ice velocity products are typically generated by cross-correlation of synthetic aperture radar (SAR) images, and do not distinguish between glaciers and sea ice. Knowing the position of the calving front line allows a flow line to be constructed based on the glacier alone, thus eliminating this problem. The calving front line product can thus act as an auxiliary data set in cases where annual movement of calving front lines must be taken into account.

\section{Conclusions}

The PROMICE calving front line product provides a useful data set of calving front lines at the end of each melt season since 1999. Area change estimates generated from earlier versions of the data set have been used in international climate status reporting, for example in the Arctic Monitoring and Assessment Programme (AMAP 2017), in the State of the Climate series (e.g. Tedesco et al. 2016) and the Arctic Report Card (Tedesco et al. 2018). The updated and extended data set now provides annual end-of-melt-season calving front lines for 47 Greenland marine terminating glaciers between 1999 and 2018. The data have been added to the list of PROMICE products, which are publicly available at www. promice.dk.

\section{Acknowledgements}

We thank one anonymous reviewer and Mette Kusk Gillespie for constructive reviews. The Programme for Monitoring of the Greenland Ice Sheet (PROMICE) is funded by the Geological Survey of Denmark and Greenland (GEUS) and the Danish Ministry of Energy, Utilities and Climate under Danish Cooperation for Environment in the Arctic (DANCEA), and is conducted in collaboration with the National Space Institute (DTU Space) and Asiaq (Greenland Survey). We would also like to thank the EU Copernicus program and ESA for Sentinel-2 data, NASA/USGS for Landsat data, and NASA/USGS/JSS (Japans space systems) for ASTER products.

\section{References}

AMAP 2017: Snow, Water, Ice and Permafrost in the Arctic (SWIPA) 2017. Arctic Monitoring and Assessment Programme (AMAP), 269 pp. Oslo, Norway.

Bevis, M.C. et al. 2019: Accelerating changes in ice mass within Greenland, and the ice sheet's sensitivity to atmospheric forcing, Proceedings of the National Academy of Sciences 116,1934-1939; https://doi. org $/ 10.1073 /$ pnas. 1806562116

Box, J.E., Colgan, W.T., Wouters, B., Burgess, D.O., O’Neel, S., Thomson, L.I., \& Mernild, S.H. 2018: Global sea-level contribution from Arctic land ice: 1971-2017. Environmental Research Letters 13, 125012. https://doi.org/10.1088/1748-9326/aaf2ed

Jensen, T.S., Box, J.E. \& Hvidberg, C.S. 2016: A sensitivity study of annual area change for Greenland ice sheet marine terminating outlet 
glaciers: 1999-2013. Journal of Glaciology 62, 72-81. https://doi. org $/ 10.1017 /$ jog.2016.12

Khazendar, A. et al. 2019: Interruption of two decades of Jakobshavn Isbrae acceleration and thinning as regional ocean cools. Nature Geoscience 12, 277-283. https://doi.org/10.1038/s41561-019-0329-3

Khan, S.A., Aschwanden, A., Bjørk, A.A., Wahr, J., Kjeldsen, K.K. \& Kjær, K.H. 2015: Greenland ice sheet mass balance: a review. Reports on Progress in Physics B, 046801. https://doi.org/10.1088/00344885/78/4/046801

Moon, T., Joughin, I., Smith, B., van den Broeke, M.R., van de Berg, W.J., Noël, B. \& Usher, M. 2014: Distinct patterns of seasonal Greenland glacier velocity. Geophysical research letters 41, 7209-7216. https:// doi.org/10.1002/2014gl061836

Moon, T., Ahlstrøm, A., Goelzer, H., Lipscomb, W. \& Nowicki, S. 2018 Rising oceans guaranteed: Arctic land ice loss and sea level rise. Current Climate Change Reports 4, 211-222. https://doi.org/10.1007/s40641018-0107-0

Nick, F.M., Vieli, A., Howat, I.M. \& Joughin, I. 2009: Large-scale changes in Greenland outlet glacier dynamics triggered at the terminus. Nature Geoscience 2, 110-114. https://doi.org/10.1038/ngeo394

Rignot, E. \& Kanagaratnam, P. 2006: Changes in the velocity structure of the Greenland Ice Sheet. Science, 311(5763), 986-990. https://doi. org/10.1126/science.1121381

Tedesco, M. et al.2016: Greenland Ice Sheet. In: Blunden, J. \& Arndt, D.S. (eds): State of the Climate in 2015. Bulletin of the American Meteorological Society 97, S140-S142. https://doi.org/10.1175/2016BAMSSt ateoftheClimate. 1

Tedesco, M. et al. 2018. Greenland Ice Sheet. In: Arctic Report Card 2018, NOAA. Accessed on 21/05/2019 at https://arctic.noaa.gov/ReportCard/Report-Card-2018/ArtMID/7878/ArticleID/781/GreenlandIce-Sheet van den Broeke, M.R., Bamber, J., Ettema, J., Rignot, E., Schrama, E., van de Berg, W.J. \& Wouters, B. 2009: Partitioning recent Greenland mass loss. Science 326, 984-986. https://doi.org/10.1126/science.1178176 van den Broeke, M.R., Box, J., Fettweis, X., Hanna, E., Noël, B., Tedesco, M., van As, D., van de Berg, W.J. \& van Kampenhout, L. 2017: Greenland ice sheet surface mass loss: recent developments in observation and modelling. Current Climate Change Reports 3, 345-356. https://doi. org/10.1007/s40641-017-0084-8

van der Veen, C.J. 1998: Fracture mechanics approach to penetration of surface crevasses on glaciers. Cold Regions Science and Technology 27, 31-47. https://doi.org/10.1016/S0165-232X(97)00022-0

Weertman, J. 1973: Can a water-filled crevasse reach the bottom surface of a glacier? International Association of Hydrological Sciences 95, 139-145.

\section{How to cite}

Andersen, J.K., Fausto, R.S., Hansen, K., Box, J.E., Andersen, S.B., Ahlstrøm, A.P., van As, D., Citterio, M., Colgan, W., Karlsson, N.B., Kjeldsen, K.K., Korsgaard, N.J., Larsen, S.H., Mankoff, K.D., Pedersen, A.Ø., Shields, C.L., Solgaard, A. \& Vandecrux, B. 2019: Update of annual calving front lines for 47 marine terminating outlet glaciers in Greenland (1999-2018). Geological Survey of Denmark and Greenland Bulletin43, e2019430202.https://doi.org/10.34194/GEUSB-201943-02-02 